\title{
Analysis of Water Quality Status in Porong River, Sidoarjo by Using NSF-WQI Index (Nasional Sanitation Foundation - Water Quality Index)
}

\author{
Muhammad Triaji ${ }^{*}$, Yenny Risjani ${ }^{2}$, Mohammad Mahmudi ${ }^{3}$ \\ ${ }^{1}$ Postgraduate Student, Faculty of Fisheries and Marine Science, Brawijaya University \\ 2 Faculty of Fisheries and Marine Science, Brawijaya University \\ ${ }^{3}$ Faculty of Fisheries and Marine Science, Brawijaya University
}

\begin{abstract}
Porong River can be described as a walking landfill that can deliver variety of waste to go to estuary, where it would be settled and accumulated. That numerous waste in the river will lead to pollution and provide huge negative impact for water quality status and organism life. Therefore, this study aim to assess the extent of contamination that occurred in Porong river by using WQI NSF (National Sanitation Foundation - Water Quality Index) Index. The research site was in along Porong river from Mojokerto to Jaban Sidoarjo estuary, which will be divided into 7 sampling sites. Next, the determination of the sampling location was conducted by using purposive sampling method. The use of WQI NSF index is able to analyze data using 8 or 9 parameters. In order to obtain complete overview of water quality status in Porong River, then this research used 9 parameters, including: BOD, DO, nitrate, total phosphate, temperature, turbidity, total solids, $\mathrm{pH}$, and Fecal Coliform. Based on the results of 9 parameters data analysis using NSF-WQI index, it is known that the recent water quality status in Porong River is classified as Medium criteria. By knowing the results of data analysis showing the criteria of medium, so we are obliged to maintain the water cleanness, so that the water quality status will not decline.
\end{abstract}

Keywords: NSF-WQI, Porong River, Status of Water Quality

\section{INTRODUCTION}

Porong River is one of large rivers coming from Brantas River. Porong River can be described as a walking landfill that can deliver variety of waste to go to estuary, where it would be settled and accumulated. The main cause of water quality declining in the Porong River is the pollution caused by disposal of industrial waste, domestic waste, agricultural pesticides remnants and Lapindo mud. Lapindo mud, which flows to Porong River also provides a negative impact on aquatic organisms and also causes silting at river Porong estuary [1]. That numerous waste in the river will lead to pollution and provide huge negative impact for water quality status and organism life. Water Quality Index (WQI) is an index that describing the quality of water at a time and location of the water. WQI make the complex quality parameters into information that is easily to understood by the public, can be used to compare water quality status in some places [2]. The result of the NSF-WQI index analysis on Ciambulawung river water, Banten shows the quality status of the water is in good condition because of the community activities and the micro-hydro activities does not give negative impact to the river water quality [3]. Therefore, thus study aims to assess the current condition of the porong river water quality by using the NSF -WQI index (National Sanitation Foundation -
Water Quality Index).

\section{MATERIAL AND METHODS}

Research site was in along Porog River from Mojokerto to Jabon Sidoarjo estuary Jabon Sidoarjo, which will be divided into 7 sampling sites. Given the short time of the study and to have the picture of the real conditions then the integration of the samples is conducted by taking the samples of water from the point in area edge-centeredge at each research station. The enforcement of sampling was conducted in August, 2016.

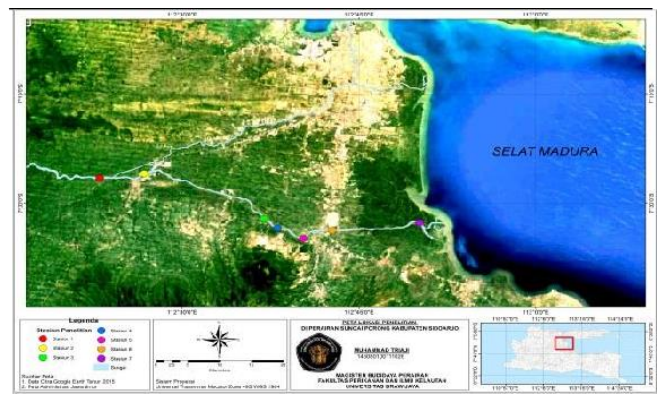

Figure 1. Research Sites in Porong River

Station 1 is an area of TBI (Taman Brantas 
Indah), station 2 which is an area of flavourings industrial waste discharge, station 3 is an area of the confluence of the Porong River and Sadar River, station 4 is the location of paper industrial waste discharge, station 5 is the confluence area of the Porong river and Raos river, station 6 is the discharge location of the Lapindo mud, and station 7 is the creek.

The determination of the sampling location was conducted by using purposive sampling method that takes into account the various considerations for waste input from households, agriculture, livestock, fisheries and business/industry activity occurring in watershed as well as the impact inflicted on the river.

\section{Data Collection Method}

In order to obtain complete overview on recent status of water quality in Porong, Sidoarjo River, and then data analysis can be carried out by using NSF-WQI index. The use of WQI NSF index is able to analyze data using 8 or 9 parameters. In order to obtain complete overview on water quality status in Porong River, then this research used 9 parameters, including: BOD, DO, nitrate, total phosphate, temperature, turbidity, total solids, $\mathrm{pH}$, and Fecal Coliform [4]. Measurement parameters (DO, Temperature, Turbidity and $\mathrm{pH}$ ) are performed in situ research sites, then the parameters (BOD, Nitrate, Total Phosphate, Total Solid, and Fecal Coliform) conducted exsitu in biotechnology laboratories waters Faculty of Fisheries and Marine Science University of Brawijaya, Malang.

Furthermore, weight from each parameter is multiplied by score obtained from sub-index curve (Li). For obtaining score of sub-index, the researcher used online NSF-WQI Calculator www.waterresearch.net/watrqualindex/waterqualityindex.htm . Next, scores from all of parameters are summed up with formula presented below:

NSF - WQI / Index of Water Quality are determined by criteria in Table 1.

$$
\begin{array}{r}
n \\
n S-W Q I=\Sigma W i \times L i \\
i=0
\end{array}
$$

Note:

$\begin{array}{ll}\text { NSF-WQI } & \text { : Index of Water Quality } \\ \mathrm{Wi} & \text { : Weight } \\ \mathrm{Li} & \text { : Scores from sub-index curve }\end{array}$

Table 1. Criteria of Index of Water Quality (NSF-WQI)

\begin{tabular}{cc}
\hline NSF-WQI Score & Criteria \\
\hline $0-25$ & Very Bad \\
$26-50$ & Bad \\
$51-70$ & Medium \\
$71-90$ & Good \\
$91-100$ & Excellent
\end{tabular}

\section{RESULT AND DISCUSSION}

Based on the result of observation and sampling in the sites, it is obtained result of water quality parameter measurement as follows Table 2.

Table 2. Result of Water Quality Parameter

\begin{tabular}{|c|c|c|c|c|c|c|c|}
\hline $\begin{array}{c}\text { Water } \\
\text { Quality } \\
\text { Parameter }\end{array}$ & St.1 & St.2 & St.3 & St.4 & St.5 & St.6 & St.7 \\
\hline $\begin{array}{c}\mathrm{DO} \\
(\mathrm{mg} / \mathrm{L})\end{array}$ & 7.62 & 6.90 & 4.83 & 5.89 & 4.93 & 4.90 & 5.38 \\
\hline Suhu $\left({ }^{\circ} \mathrm{C}\right)$ & $29^{\circ} \mathrm{C}$ & $29^{\circ} \mathrm{C}$ & $29^{\circ} \mathrm{C}$ & $29^{\circ} \mathrm{C}$ & $28^{\circ} \mathrm{C}$ & $28^{\circ} \mathrm{C}$ & $28^{\circ} \mathrm{C}$ \\
\hline $\begin{array}{c}\text { BOD } \\
\text { (mg/L) }\end{array}$ & 3.12 & 1.35 & 1.13 & 1.47 & 2.16 & 1.6 & 2.68 \\
\hline $\begin{array}{c}\text { Total Solids } \\
\text { (mg/L) }\end{array}$ & 9 & 26 & 223 & 44 & 42 & 175 & 55 \\
\hline Turbidity & 12 & 8 & 41 & 8 & 12 & 68 & 26 \\
\hline $\begin{array}{c}\text { Nitrat } \\
\text { (mg/L) } \\
\text { Total }\end{array}$ & 4.8 & 5.1 & 4.8 & 4.7 & 4.9 & 6.2 & 5 \\
\hline $\begin{array}{l}\text { Pospat } \\
\text { (mg/L) }\end{array}$ & 0.109 & 0.080 & 0.068 & 0.068 & 0.068 & 0.061 & 0.036 \\
\hline $\mathrm{pH}$ & 8.1 & 6.8 & 7.7 & 7.9 & 7.6 & 8.1 & 7.8 \\
\hline $\begin{array}{c}\text { E.Coli } \\
\Sigma / 100 \mathrm{ml}\end{array}$ & 20 & 150 & 39 & 93 & 210 & 210 & 120 \\
\hline
\end{tabular}
Measurement

Based on result of data analysis of water quality by using NSF-WQI (Nasional Sanitation Foundation- Water Quality Index), it is known that water in Porong River is classified as medium criteria. Medium criteria is obtained due to the low value of the DO curve sub-index, and total phosphate so that when multiplied by the weight parameter, the value is still low so it does not much alter the amount of the final total score of NFS-WQI. The result can be seen in Table 3.

Table 3. The Result of Water Quality in Porong River Using NSF-WQI Method

\begin{tabular}{cccc}
\hline No. & Sampling Sites & $\begin{array}{c}\text { Skor NSF- } \\
\text { WQI }\end{array}$ & Criteria \\
\hline 1 & Station 1 & $\mathbf{5 7 . 4 9}$ & Medium \\
2 & Station 2 & $\mathbf{5 8 . 6 2}$ & Medium \\
3 & Station 3 & $\mathbf{5 6 . 5}$ & Medium \\
4 & Station 4 & $\mathbf{5 9 . 8 9}$ & Medium \\
5 & Station 5 & $\mathbf{5 7 . 5 5}$ & Medium \\
6 & Station 6 & $\mathbf{5 2 . 4 1}$ & Medium \\
7 & Station 7 & $\mathbf{5 6 . 4 1}$ & Medium
\end{tabular}


Analysis of river water quality status of Ciambulawung using NSF-WQI with 8 major parameters indicate the water criteria classified as good by the score (87-88). This is in contrast with the analysis of the river water quality status of Porong by using 9 parameters indicate medium criteria with a score $(52,41-59,89)$. The use of 9 parameters was intended to have further description on actual condition in nature due to organic material effect, because basically, this method was used to assume waters that are more affected by organic material rather than heavy metals [2].

\section{CONCLUSION}

Based on result of 9 parameters data analysis using NSF-WQi (Nasional Sanitation FoundationWater Quality Index) index, it is known that the recent status of water quality in Porong, River is classified as Medium criteria with a score of 52, 4159.89. By knowing results of data analysis showing the criteria of medium, so we are obliged to maintain the water river cleanness, so that the water quality status will not decline. Besides, it is also expected that there would be another study focus on water quality status in Porong River, which is based on water organism in it.

\section{ACKNOWLEDGMENT}

The writer thanks to Prof. Ir. Yenny Risjani, DEA. Ph.D and Dr. Ir. Mohammad Mahmudi, MS, as a assessor team which assess the writer from the beginning until the final of the research.

\section{REFERENCES}

[1]. Sari A. E. M, T. Purnomo, dan Winarsih. 2013. Kualitas Perairan Estuari Porong Sidoarjo Jawa Timur Berdasarkan Indeks Keanekaragaman Makrozoobentos. LenteraBio Vol. 2 No. 1 Januari 2013:81-85

[2]. Muslimin, dan S. P Sarawati. 2012. Kajian Status Mutu Air Di Sungai Gajahwong Dengan Berbagai Indeks Kualitas Air. Lingkungan Tropis, vol. 6, no.2, September 2012: 91-103

[3]. Romanto. 2013. Status Kualitas Air Sungai Ciambulawung, Banten. Skripsi. Departemen manajemen sumber daya perairan. Fakultas Perikanan Dan IImu Kelautan. Institut Pertanian Bogor.

[4]. Effendi H. 2015. Simulasi penentuan indeks pencemaran dan indeks kualitas air (NSF-WQI). Puslitbang Kualitas dan Laboratorium Lingkungan Kementerian Lingkungan Hidup dan Kehutanan. 16 oktober 2015. Jakarta 